\title{
PROGRAM KEMITRAAN MASYARAKAT: PELATIHAN PEMBUATAN MAKANAN SEHAT UNTUK PROGRAM DIET ALAMI YANG BERGIZI UNTUK KELOMPOK IBU-IBU DI SAMARINDA
}

\author{
Sabalius Uhai ${ }^{1)}$ dan I Wayan Sudarmayasa ${ }^{2)}$ \\ ${ }^{1,2}$ Jurusan Pariwisata, Politeknik Negeri Samarinda \\ ${ }^{1,2}$ J1. Ciptomangunkusumo Kampus Gunung Panjang, Kota Samarinda, kodepos 75131 \\ E-mail : sabaliusuhai@polnes.ac.id ${ }^{1)}$, i_w_sudarmayasa@polnes.ac.id ${ }^{2}$
}

\begin{abstract}
ABSTRAK
Kegiatan pelatihan pembuatan makanan sehat untuk program diet alami yang bergizi untuk kelompok ibu- ibu di kota Samarinda ini adalah sebuah kegiatan pengabdian kepada masyarakat yang diselenggarakan oleh Jurusan Pariwisata dan didanai oleh UPT. Pusat Penelitian dan Pengabdian Masyarakat (P3M) Politeknik Negeri Samarinda. Adapun kegiatan ini diadakan di kelurahan Harapan Baru Kecamatan Loa Janan Ilir, Kota Samarinda Kalimantan Timur. Adapun tujuan dari kegiatan pengabdian kepada masyarakat adalah memberikan pemahaman dan pengetahuan yang baik dan benar bagaimana caranya menjalankan diet sehat bergizi dengan menggunakan bahan buah-buahan. Peserta dari kegiatan ini adalah masyarakat yang ada di sekitar kelurahan Harapan Baru, peserta kegiatan diutus oleh beberapa RT (Rukun Tetangga) yang ada di wilayah Harapan Baru. Metode pelaksanaan kegiatan pengabdian ini adalah pertama peserta diberikan materi tentang jenis-jenis buah yang dapat digunakan untuk diet sehat, selain itu dijelaskan juga manfaat dari masing-masing buah.. Dalam kegiatan pengabdian kepada masyarakat ini menggunakan buah pisang, apel, jeruk, melon, pepaya dan chia seed. Kedua kegiatan pengabdian kepada masyarakat ini juga menggunakan metode partisipatif yakni adanya keterlibatan dari peserta.. Dengan pelatihan ini diharapkan ada perubahan dalam pengelolaan makanan sehat dengan menggunakan buah-buahan selain itu harapkan para peserta pelatihan memiliki badan yang sehat serta ideal yakni adanya kesesuaian antara berat badan dengan tinggi badan.
\end{abstract}

Kata Kunci: Pengabdian kepada masyarakat, Makanan sehat, Diet alami, bergizi, buah-buahan,

\section{PENDAHULUAN}

Dalam UU No 36 Tahun 2009 tentang Kesehatan menyatakan Pembangunan kesehatan bertujuan untuk meningkatkan kesadaran, kemauan, dan kemampuan hidup sehat bagi setiap orang agar terwujud derajat kesehatan masyarakat yang setinggi-tingginya, sebagai investasi bagi pembangunan sumber daya manusia yang produktif secara sosial dan ekonomis (Presiden RI, 2009). Gerakan Masyarakat Hidup Sehat (GERMAS) merupakan suatu tindakan sistematis dan terencana yang dilakukan secara bersama-sama oleh seluruh komponen bangsa dengan kesadaran, kemauan dan kemampuan berperilaku sehat untuk meningkatkan kualitas hidup.

Instruksi Presiden RI(Presiden RI, 2017) tentang gerakan masyarakat sehat (GERMAS) dapat dilakukan dengan cara: Melakukan aktifitas fisik, Mengonsumsi sayur dan buah, Tidak merokok, Tidak mengkonsumsi alkohol, Memeriksa kesehatan secara rutin, Membersihkan lingkungan, dan Menggunakan jamban. Pada tahap awal, GERMAS secara nasional dimulai dengan berfokus pada tiga kegiatan, yaitu: 1) Melakukan aktivitas fisik 30 menit per hari, 2) Mengonsumsi buah dan sayur; dan 3) Memeriksakan kesehatan secara rutin (Ambartana, 2019).
Kebiasaan mengkonsumsi makanan sehat telah berubah akibat perkembangan ekonomi yang begitu pesat (Adenengsi, 2019). Organisasi Kesehatan Dunia (WHO) sangat peduli dengan kecenderungan terjadinya peningkatan obesitas dan penyakit tidak menular yang mempengaruhi masalah kesehatan utama negara-negara di dunia. Jumlah kasus baru obesitas dalam 2 dekade mendatang diperkirakan akan melebihi ratusan juta(Ellulu, 2014).

Gaya hidup perkotaan saat ini diet menjadi sebuah pilihan di mana ketika seseorang ingin memiliki badan yang ideal. Tingginya tingkat obesitas di kehidupan perkotaan adalah karena tidak adanya kedisiplinan dalam memilih makanan yang dimakan. Jumlah kalori yang masuk dalam tubuh tidak sama dengan kalori yang dibutuhkan oleh tubuh. Belum lagi ketika padatnya pekerjaan membuat seseorang tidak ada waktu untuk melakukan kegiatan olahraga. Diet merupakan salah satu cara yang dapat digunakan untuk membuat tubuh menjadi ideal yakni antara berat badan dan tinggi badan yang sesuai. Kegiatan diet akan berhasil jika dilakukan dengan cara yang tepat, benar dan sesuai kebutuhan tubuh selain itu disiplin dalam melaksanakan kegiatan diet juga sangat dituntut. 
Dalam kehidupan rumah tangga terkadang seseorang jarang memperhatikan kesehatan, bahkan dalam hal makan pun tidak bisa diatur, semua makanan masuk dalam perut tanpa memperhatikan apakah makanan tersebut sehat atau tidak, bahkan sering didengar makan saja biar perut yang atur. Seseorang akan memperhatikan pola makan ketika sudah mulai muncul berbagai macam penyakit.

Buah-buahan adalah makanan yang baik dan sehat. buah adalah satu bagian dari tanaman dalam satu pohon yang memiliki daging serta dapat dikonsumsi menjadi makanan sehingga dapat memberikan efek menyenangkan, menyehatkan dan yang paling penting mengenyangkan. Buah-buahan dapat digunakan sebagai bahan makanan diet sehat. Buah-buahan ini dikonsumsi pada saat perut masih kosong, artinya seorang belum makan. Banyak manfaat dari konsumsi buah-buahan bagi tubuh manusia oleh karena itu sangat disarankan untuk mengkonsumsi buah-buahan.

Mengatasi masalah diatas tentang bagaimana agar para ibu-ibu dapat memiliki badan yang ideal, maka diperlukan kegiatan Pelatihan pembuatan makanan sehat untuk program diet alami yang bergizi untuk kelompok ibu-ibu di kota Samarinda, kegiatan ini diadakan di kelurahan harapan baru kecamatan Loa Janan Ilir. Adapun tujuan dari kegiatan ini adalah agar para ibu-ibu rumah tangga dapat melaksanakan diet sehat dengan menggunakan buah-buahan yang mudah didapatkan di pasar. Tujuan berikutnya ada agar para ibu rumah tangga memiliki badan yang ideal, dengan demikian akan lebih disayang oleh para suami.

\section{RUANG LINGKUP}

Kegiatan pengabdian ini difokuskan pada :

1. Membahas tentang program diet sehat dengan menggunakan bahan buah-buahan

2. Bagaimana cara memilih buah-buahan yang cocok atau sesuai dengan kondisi tubuh.

3. Bahan yang digunakan dalam kegiatan pengabdian kepada masyarakat ini menggunakan buah pisang, apel, jeruk, melon, pepaya dan chia seed.

\section{BAHAN DAN METODE}

Kegiatan Pengabdian Kepada Masyarakat di Kelurahan Harapan Baru, Kecamatan Loa Janan Ilir Kota Samarinda merupakan sebuah upaya dalam membantu para ibu-ibu yang menginginkan badan yang sehat dan memiliki ukuran tubuh yang ideal yakni adanya kesesuaian antara tinggi badan dan berat badan. Oleh karena itu para ibu-ibu diajarkan bagaimana cara memilih buah-buahan yang sesuai dengan kondisi badan, cara mengolah buah yang baik dan benar, kapan buahbuah tersebut akan dikonsumsi.

Dalam penulisan ini disajikan bahan kajian teoritis dan metode pengabdian kepada masyarakat. Apapun metode yang digunakan adalah partisipatif peserta kegiatan.

\subsection{Kajian Empirik}

Program Pengabdian kepada masyarakat adalah sebuah kegiatan yang peduli terhadap kondisi masyarakat (Nelly Apriningrum, 2018), (Afriany, dkk, 2018), (Purwandari, 2018). Kesehatan merupakan aspek terpenting dalam kehidupan dan mendukung berjalannya aktivitas secara optimal. Kesehatan diartikan sebagai kondisi fisik,mental dan sosial yang terbebas dari gangguan penyakit sehingga aktivitas yang berjalan di dalamnya dapat terjadi secara optimal(Endang Susanti, 2018) .

Diet adalah serangkaian susunan jumlah dan jenis makanan dan minuman yang dikonsumsi seseorang dari hari ke hari (Nugraha, 2016). Pengetahuan masyarakat tentang kesehatan, hidup sehat merupakan sebuah usaha supaya kondisi badan menjadi lebih baik (Damaiyanti dan Hardyanti, 2015). Konsumsi jus untuk menurunkan berat badan (Priyo, 2020).

\subsection{Tahap Kegiatan}

Tahap awal dari kegiatan ini adalah melakukan pembuatan proposal pengajuan ke Program Kemitraan Masyarakat Politeknik Negeri Samarinda. Sebelum proposal dibuatkan diadakan survey dengan mitra pelatihan yakni kelurahan Harapan Baru dengan bekerjasama dengan ketua Lembaga Pemberdayaan Masyarakat (LPM) Harapan Baru, Ketua LPM kelurahan Harapan Baru sangat bersemangat menerima kegiatan pelatihan ini di mana kegiatan ini sangat membantu masyarakat dalam memahami program diet sehat.

Pelaksanaan kegiatan Pengabdian kepada Masyarakat ini menggunakan metode partisipatif yakni adanya kerjasama antara narasumber dengan peserta. Dalam proses pembuatan makanan sehat ini ibu-ibu terlibat secara langsung mulai proses pemilihan buah, mengupas buah, memotong dan memblender buah-buahan.

\section{PEMBAHASAN}

Pengabdian Kepada Masyarakat ini dilaksanakan melalui dua tahap, yakni bagian pertama adalah pemaparan materi tentang buah-buahan yang digunakan dalam program diet sehat adapun tujuan dari uraian mengenai bahan-bahan tersebut agar peserta dapat memahami manfaat dari masing-masing buah tersebut, sedangkan tahap kedua adalah melakukan praktikum mengolah buah-buahan menjadi minuman atau makanan sehat.

\subsection{Tahap Pertama}

Materi pelatihan pembuatan makanan sehat untuk program diet alami yang bergizi untuk kelompok ibu-ibu disampaikan oleh Bapak Junai Shalat. Lihat gambar 1, Bapak Junai Shalat adalah seorang alumni dari Jurusan Pariwisata Politeknik Negeri Samarinda, sejak lulus kuliah langsung kerja di hotel dengan menekuni dunia 
kuliner, menguasai masakan nusantara, Eropa dan masakan China. Bapak Junaidi Shalat juga sebagai anggota ICA (Indonesian Chef Association) selain itu Bapak Junaidi Shalat di hotel biasa dipanggil Chef Jun.

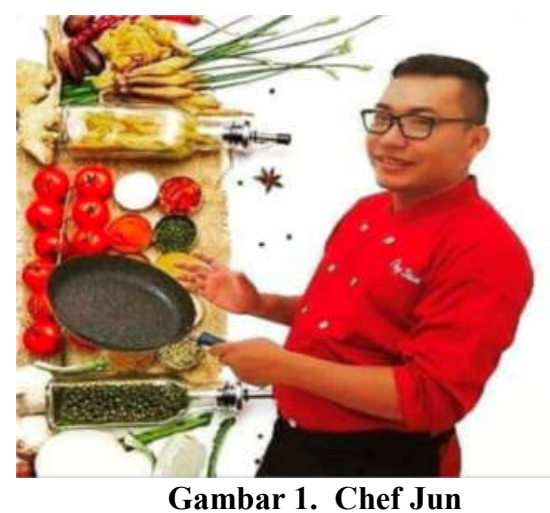

Dalam pengenalan makanan diet sehat pemateri yakni Chef Jun menjelaskan beberapa buah (lihat gambar 2) yang baik untuk kesehatan. Adapun beberapa buah yang cocok untuk diet sehat adalah

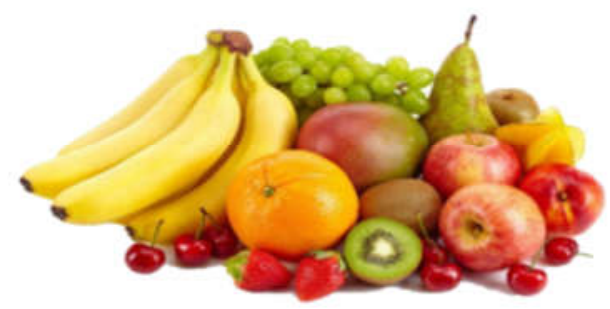

Gambar 2. Buah-buahan sehat

\section{Pisang}

Buah pisang adalah buah yang sangat terkenal dan banyak yang minat makan buah ini. Dalam proses konsumsi ada yang dimakan langsung, digoreng, direbus, dikukus, bahkan bisa diolah untuk membuat bermacam jenis kue.

Pisang (Musa paradisiaca) merupakan tanaman yang sudah sangat populer di Indonesia. Namun, budidaya pisang belum dilakukan secara efisien karena belum diusahakan secara perkebunan yang menguntungkan. Kebanyakan pisang ditanam oleh rakyat sebagai bahan selingan atau sebagian saja di lahan-lahan pekarangan (Winarti, 2010). Adapun manfaat dari konsumsi buah pisang adalah membantu atasi hipertensi, sumber karbohidrat dan vitamin A, pisang memperlancar metabolisme, meningkatkan kekebalan tubuh, melancarkan aliran oksigen ke otak, mengatasi anemia, menurunkan berat badan, menyehatkan tulang, pisang sebagai "Mood Food", untuk merawat kulit(P2PTM Kemenkes RI, 2018). Manfaat kandungan dalam pisang adalah nutrisi alami untuk mengatur kadar gula darah, kaya serat yang baik untuk tubuh, rendah kalori, berguna untuk menurunkan berat badan, mengandung kalium yang penting untuk kesehatan jantung, tinggi antioksidan, mampu menangkal radikal bebas, kalium juga membantu mengontrol tekanan darah, sumber pati resisten yang baik, dapat meningkatkan sensitivitas insulin (Sayurbox, 2020)

\section{Apel}

Apel sudah lama dikenal sebagai salah satu buah yang dapat menyehatkan tubuh. Bahkan di masyarakat sempat muncul istilah "An Apple A Day Keeps The Doctor Away" yang dapat diartikan, makan apel setiap hari dapat mencegah datangnya penyakit. Adapun manfaat dari buah apel adalah Salah satu zat gizi penting yang terdapat pada apel adalah vitamin $C$, Apel juga kaya dengan antioksidan quercetin dan polifenol, Apel termasuk buah yang kaya akan serat. Kulit apel merupakan sumber serat tidak larut selulosa dan lignin, Di dalam daging buahnya, apel banyak mengandung pektin, yaitu serat kasar menyerupai gel yang larut dalam air. Zat tersebut diketahui merupakan zat antidiare alami karena dapat melindungi selaput lendir lambung dan usus dari luka dan serangan bakteri, Pektin di dalam apel juga dapat membantu menurunkan kolesterol dengan cara menyerap lemak dan kolesterol, lalu mengeluarkannya dari dalam tubuh bersama feses, Apel pun mengandung senyawa kimia berkhasiat lainnya, yaitu senyawa butyrate (Sapto, 2020).

\section{Jeruk}

Manfaat jeruk memang sangat banyak bagi tubuh. Jeruk adalah salah satu buah paling populer di dunia. Jeruk hampir dapat ditemui di berbagai belahan dunia. Jeruk terdiri dari berbagai jenis seperti jeruk manis, jeruk nipis, lemon, jeruk bali dan masih banyak lagi. Semuanya memiliki manfaat jeruk yang luar biasa. Jika Anda ingin memenuhi nutrisi harian, buah jeruk menjadi salah satu pilihan tepat. Jeruk biasa dikonsumsi langsung, di jus, atau sebagai campuran makanan dan minuman. Berikut manfaat jeruk: melawan kanker, meningkatkan kesehatan jantung, melindungi fungsi otak, kesehatan kulit, mengurangi risiko diabetes, pencegahan anemia (Sendari, 2019)

\section{Melon}

Buah melon memiliki berbagai nutrisi di dalamnya, seperti kalium, asam folat, protein, vitamin, betakaroten, dan magnesium. Buah melon memiliki rasa manis dan hampir 95 persen mengandung air. Kandungan air yang banyak pada buah melon itu dapat menuntaskan dahaga Anda. Manfaat mengkonsumsi buah melon yakni menurunkan tekanan darah tinggi, menjaga kesehatan mata, mencegah penyakit jantung, menjaga kesehatan pencernaan, menyehatkan tulang, dapat mencegah penyakit kanker, menurunkan berat badan (Yuda, 2020). 


\section{Pepaya}

Pepaya memang menjadi salah satu buah paling banyak disukai oleh anak-anak hingga orang dewasa. Tak hanya rasanya yang enak, buah ini juga memiliki banyak kandungan mineral dan vitamin. Buah pepaya banyak manfaatnya bagi kesehatan tubuh. Salah satunya, sangat ampuh menjaga kesehatan pencernaan. Tak hanya itu saja, berikut ini beberapa manfaat buah pepaya bagi kesehatan tubuh yakni meningkatkan imun tubuh, melindungi jantung, melindungi dari kanker, mengurangi risiko alzheimer, lindungi mata, membantu diet sehat, mencegah peradangan, sistem pencernaan, mencegah penyakit asma, menurunkan kolesterol, pepaya kaya serat, vitamin $\mathrm{C}$, dan antioksidan yang mencegah penumpukan kolesterol di arteri Anda. Terlalu banyak penumpukan kolesterol dapat menyebabkan beberapa penyakit jantung termasuk serangan jantung dan hipertensi (Arianti, 2020).

\section{Chia Seed}

Chia seed atau biji chia merupakan biji hitam kecil dari tumbuhan Salvia hispanica. Biji chia banyak dikonsumsi bagi mereka yang menerapkan pola hidup sehat. Kendati ukurannya kecil, chia seed kaya nutrisi penting bagi kesehatan tubuh. Menurut laporan Medical News Today, biji chia merupakan sumber omega-3, antioksidan, serat, zat besi, dan kalsium. Semua kandungan tersebut tentu sangat dibutuhkan oleh tubuh. Berikut adalah manfaat chia seed atau biji chia bagi kesehatan yang jarang diketahui, seperti:

1. Membantu menurunkan berat badan

2. Menurunkan kadar kolesterol dan menjaga kesehatan jantung

3. Menjaga kesehatan tulang dan gigi

4. Mencegah kanker

5. Menjaga kesehatan kulit

Selain bermanfaat untuk kesehatan, biji chia juga berkhasiat bagi kecantikan, termasuk mencegah penuaan dini. Awet muda merupakan dambaan bagi banyak orang. Chia seed mampu mengurangi gejala penuaan seperti perubahan warna kulit, keriput, bintik hitam, garis harus atau kerutan, dan lain sebagainya (Novie, 2020).

\subsection{Tahap Kedua}

Pada tahap kedua ini adalah para ibu-ibu diminta untuk praktik mengolah bagaimana membuat makanan sehat secara khusus untuk diet sehat bergizi. Adapun kegiatan pada tahap kedua adalah sebagai berikut:

1. Gambar 3 menunjukkan kegiatan mempersiapkan bahan buah-buahan yakni pisang, apel, jeruk, melon, pepaya, chia seed.

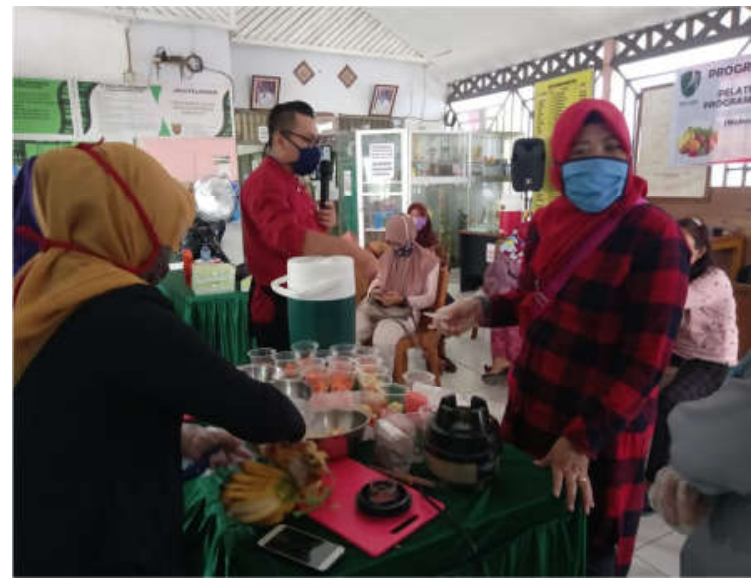

Gambar 3. Persiapan praktikum

2. Pembuatan Juice

Buah-buahan yang digunakan ini ada yang dikonsumsikan secara langsung, ada yang di blender terlebih dahulu baru dikonsumsi (lihat gambar 4). Minuman yang dibuat dalam bentuk juice, minuman juice ini sangat baik buat kesehatan secara khusus untuk yang menggunakannya sebagai sarana diet sehat. Namun perlu diingat bahwa saat membuat juice disarankan untuk tidak menambah bahan lain misalnya gula, susu. Jika sudah menambah susu dan gula makanya namanya bukan juice lagi melainkan smoothie. Mengapa gula dan susu tidak disarankan dalam membuat juice karena gula ini bahkan sebagai penyebab dari kenaikan berat badan. Dalam pembuatan juice ini boleh dicampurkan beberapa buah, misalnya buah melon dengan buah pepaya, buah apel dengan buah melon, pisang dengan buah apel. Bahkan boleh juga dicampur dengan chia seed. Untuk pencampuran buah ini akan tergantung dari selera ibu-ibu yang mau melaksanakan program diet sehat.

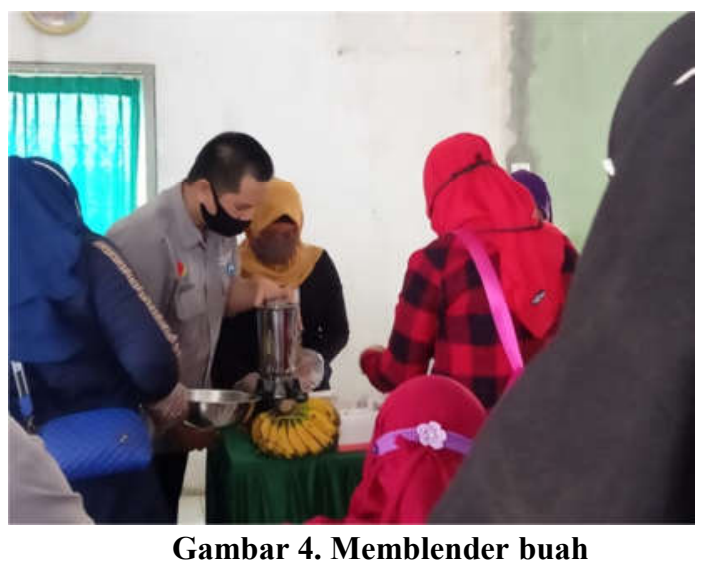

3. Hasil dari praktikum (lihat gambar 5) pengolahan diet sehat. Setelah buah-buahan di blender di masukan dalam gelas yang sudah disediakan. Untuk juice 
boleh dicampur beberapa buah-buahan tergantung dari selera atau kesukaan dari peserta.

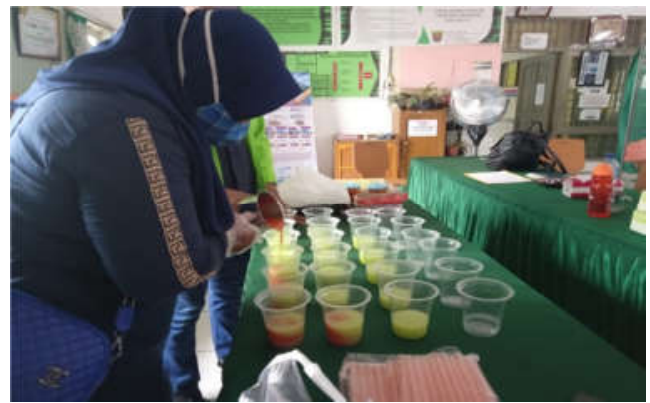

Gambar 5. Hasil praktikum

4. Sesi tanya jawab

Dalam kegiatan pengabdian ini Chef Jun (lihat gambar 6) memberikan kesempatan kepada peserta untuk bertanya tentang keluhan dan pemasalahan yang dihadapi secara khusus tentang program diet yang dilakukan oleh para peserta. Peserta boleh menanyakan tentang program diet.

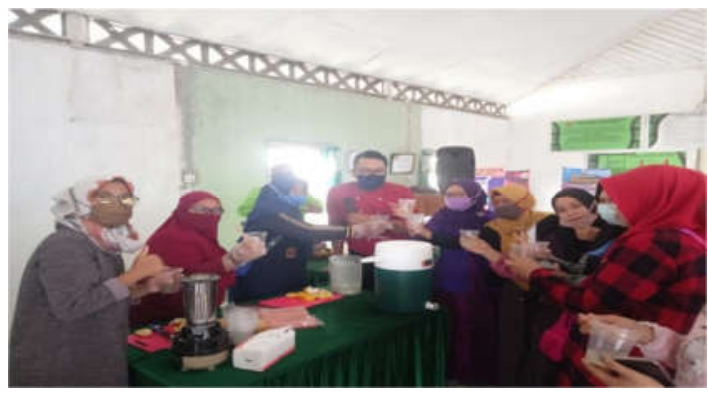

Gambar 6. Chef Jun berbagi pengalaman tentang diet sehat dari buah-buahan

\section{KESIMPULAN}

Pengabdian kepada masyarakat ini adalah sebuah Kegiatan pelatihan pembuatan makanan sehat untuk program diet alami untuk kelompok ibu-ibu bertujuan untuk membantu para ibu-ibu untuk mengetahui cara yang baik dan benar dalam melaksanakan proses diet sehat. Program diet ini diawali dengan cara memilih buah-buahan yang cocok dalam melakukan diet sehat, selain itu diharapkan para ibu-ibu konsisten dalam melaksanakan diet sehat. Para ibu-ibu sangat bersemangat dalam mengikuti pelatihan ini dimana akan menambah pemahaman tentang konsumsi buah yang baik.

\section{SARAN}

Sebuah teori tidak ada gunanya jika tidak dipraktekkan secara nyata, pihak Jurusan Pariwisata POLNES telah berbagi ilmu dan pengalaman semoga apa yang telah dibagikan dapat bermanfaat. Hanya orang yang memiliki komitmen dan disiplin yang tinggi yang dapat menjadi orang yang sukses termasuk dalam pelaksanaan diet sehat. Adapun dampak yang diharapkan dari kegiatan ini adalah adanya perubahan pola hidup secara khusus dalam menjaga kebugaran tubuh. Disarankan setelah kegiatan ini ibu-ibu dapat mengaplikasi ilmu yang telah mereka peroleh dengan baik dan menjadi pribad yang baik dan sehat.

\section{DAFTAR PUSTAKA}

Adenengsi, Y., \& Rusman, A. D. P. 2019. Hubungan Food Choice Terhadap Kesehatan Mental Pada Remaja Di Kota Parepare. Jurnal Ilmiah Manusia Dan Kesehatan, 2(3), 410-422. https://doi.org/https://doi.org/10.31850/makes.v2i 3.185 .

Afriany, J., Andrea, R., Yulsilviana, E., Wijayanti, S., \& Nabile, D. 2018. Program Pengabdian Masyarakat: Alat Bantu Belajar Ilmu Batuan Berbasis Android pada Kelas Geologi Tambang Smk Negeri 1 Sendawar. Sebatik, 22(2), 202-210.

Ambartana, I. W., \& Nursanyoto, H. 2019. Sosialisasi Manfaat Makan Sayur dan Buah Serta Manfaat Olahraga untuk Mencegah Obesitas Pada Lansia di Kecamatan Ubud Kabupaten Gianyar. Jurnal Pengabmas Masyarakat Sehat (JPMS), 1(1).

Apriningrum, N., \& Rahayu, M. A. 2018. Program Kemitraan Masyarakat: Optimalisasi Paud Holistik di Desa Lemahmulya Kecamatan Majalaya Kabupaten Karawang. Sebatik, 22(2), 235-239.

Arianti K, Marbun, dr. P. 2020. Wajib Tahu, Ini Manfaat Pepaya yang Kaya Gizi bagi Kesehatan Tubuh.

GoodDoctor. https://www.gooddoctor.co.id/tipskesehatan/nutrisi/manfaat-pepaya-bagi-tubuh/

Damaiyanti, S., \& Hardyanti, C. 2015. Hubungan Pengetahuan Ibu Rumah Tangga Dan Peran Kader Dengan Perilaku Hidup Bersih Dan Sehat (PHBS) Dalam Rumah Tangga Di Kelurahan Laing Wilayah Kerja Puskesmas Nan Balimo Kecamatan Tanjung Harapan Kota Solok Tahun 2014. 'AFIYAH, 2(1).

Novie Rachmayanti. (n.d.), 2020. 5 Manfaat Chia Seed bagi Kesehatan, Ampuh Turunkan Berat Badan. Bola.Com. Retrieved September 14, from https://www.bola.com/ragam/read/4117072/5manfaat-chia-seed-bagi-kesehatan-ampuhturunkan-berat-badan.

Nugraha, A. S., Sugianto, I., \& Prasetyo, T. F. 2016. APLIKASI SISTEM PAKAR CARA DIET BERDASARKAN GOLONGAN DARAH (Studi Kasus: Masyarakat Majalengka). J-ENSITEC, 3(01).

P2PTM Kemenkes RI. 2018. Khasiat dan Manfaat Pisang. Kementerian Kesehatan RI. http://www.p2ptm.kemkes.go.id/artikelsehat/khasiat-dan-manfaat-pisang. 
Presiden RI. 2009. UU RI tentang Kesehatan. UU RI. Presiden RI. 2017. Intruksi Presiden RI No 1 Tahun 2017 tentang Gerakan Masyarakat Hidup Sehat. UU RI.

Priyo, P., \& Priyanto, S. 2020. Efektifitas Juice Semangka Dan Senam Kebugaran Terhadap Penurunan Berat Badan Pada Anak Obesitas. Journal of Holistic Nursing Science, 7(1), 62-70.

Purwandari, D. A., Yuliani, S., \& Scorviana, N. 2018. Program Pengabdian Masyarakat: Pengelolaan Hutan Bakau dengan Pendekatan Bank Sampah. Sebatik, 22(2), 147-152.

Sapto, I. A. 2020. 8 Manfaat Apel, Jaga Imunitas hingga Turunkan Risiko Penyakit Jantung. Kompas.Com. https://health.kompas.com/read/2020/05/23/180000 068/8-manfaat-apel-jaga-imunitas-hinggaturunkan-risiko-penyakit-jantung?page=all.

Sayurbox. 2020. 7 Kandungan Pisang dan Manfaatnya untuk Kesehatan. SAYURBOX. http://blog.sayurbox.com/7-kandungan-pisang-danmanfaatnya/

Sendari. A.A 2019. 7 Manfaat Jeruk Bagi Tubuh, Tak Hanya Kaya Vitamin C. Liputan6. https:/hot.liputan6.com/read/3939256/7-manfaatjeruk-bagi-tubuh-tak-hanya-kaya-vitamin-c.

Susanti, E., \& Kholisoh, N. 2018. Konstruksi Makna Kualitas Hidup Sehat (Studi Fenomenologi pada Anggota Komunitas Herbalife Klub Sehat Ersand di Jakarta). LUGAS Jurnal Komunikasi, 2(1), 1-12.

Winarti, S. 2010. Makanan fungsional. Yogyakarta: Graha Ilmu, 137-165.

Yuda. A. 2020. 7 Manfaat Melon, Buah Ideal untuk Program Diet. Bola.Com. https:/www.bola.com/ragam/read/4241468/7manfaat-melon-buah-ideal-untuk-programdiet\#: :text=Menurunkan Berat Badan\&text=Buah melon dapat membuat Anda,merupakan buah yang rendah kalori.

\section{UCAPAN TERIMA KASIH}

Terima kasih kami haturkan kepada Manajemen POLNES, P3M POLNES, Jurusan Pariwisata POLNES serta kelurahan Harapan Baru serta para peserta yang terlibat dalam kegiatan pelatihan ini. 